\title{
Quantification of mRNA for the vitamin D metabolizing enzymes CYP27B1 and CYP24 and vitamin D receptor in kidney using real-time reverse transcriptase- polymerase chain reaction
}

\author{
P H Anderson ${ }^{1,3}$, P D O'Loughlin ${ }^{2,3}$, B K May ${ }^{1,3}$ and H A Morris ${ }^{1,3}$ \\ ${ }^{1}$ Hanson Institute, Frome Road, Adelaide, South Australia, 5000, Australia \\ ${ }^{2}$ Clinical Biochemistry, Institute of Medical and Veterinary Science, Frome Road, Adelaide, South Australia 5000, Australia \\ ${ }^{3}$ School of Molecular and Biomedical Science, University of Adelaide, North Tce, Adelaide, South Australia 5005, Australia \\ (Requests for offprints should be addressed to P H Anderson, Hanson Institute, Frome Road, Adelaide, South Australia 5000, Australia; \\ Email: paul.anderson@ adelaide.edu.au)
}

\begin{abstract}
Critical to an understanding of the control of 1,25-dihydroxyvitamin $D(1,25 D)$ activity is a molecular appreciation of the regulation of three genes, 25-hydroxyvitamin D-1 $\alpha$-hydroxylase (CYP27B1), 25-hydroxyvitamin D-24-hydroxylase (CYP24) and vitamin D receptor (VDR). We now report the sensitivity, reproducibility and accuracy of a real-time reverse transcriptase-polymerase chain reaction protocol (Taqman) for the quantification of mRNA levels for these genes in total RNA extracted from kidney tissue. The sensitivity of the protocol was at least 150 copies of mRNA per reaction. Reproducibility, expressed as the coefficient of variation, ranged between 14 and $30 \%$ at the level of approximately $10^{4}$ copies of mRNA per reaction. Accuracy was estimated at greater than $95 \%$ for each of these mRNAs. This protocol allows for the comparison of absolute mRNA levels in extracted total RNA in kidneys from animals fed diets containing different levels of calcium, ranging from $0.05 \%$ to $1 \%$. Serum $1,25 \mathrm{D}$ levels were decreased when the dietary calcium concentration was increased $(P<0.05)$. The levels of CYP27B1 mRNA were highest in the animals fed the $0.05 \%$ calcium diet $(P<0.01)$. Conversely, CYP24 and VDR mRNA levels were highest in the animals fed the $1 \%$ calcium diet $(P<0.01)$. Both CYP27B1 and CYP24 mRNA levels were major determinants of serum 1,25D levels when dietary calcium intakes were varied in these adult animals (Multiple $\mathrm{R}^{2}=0.70, P<0.01$ ). No significant relationship was detected between kidney CYP27B1 and serum parathyroid hormone (PTH) suggesting that serum calcium may regulate CYP27B1 mRNA expression directly during normocalcaemia. Low levels of CYP24 mRNA were associated with high PTH levels. These findings suggest that kidney CYP24 activity, possibly regulated by factors such as PTH, acts in concert with kidney CYP27B1 to control serum 1,25D levels.
\end{abstract}

Journal of Molecular Endocrinology (2003) 31, 123-132

\section{Introduction}

Details of the regulatory mechanisms determining the level of activity of the secosteroid, 1,25dihydroxyvitamin $\mathrm{D}_{3}(1,25 \mathrm{D})$ and particularly the role of $1,25 \mathrm{D}$ in the modulation and maintenance of serum calcium levels and bone mineralisation remain to be elucidated. The current paradigm for the maintenance of calcium homeostasis is that when blood calcium levels are low, an increase in parathyroid hormone (PTH) levels acts at the kidney to increase the reabsorption of calcium and stimulate the production of $1,25 \mathrm{D}$, which in turn stimulate the absorption of calcium in the intestine (O'Loughlin \& Morris 1998). The major site of production of circulating $1,25 \mathrm{D}$ is the kidney, where the mitochondrial cytochrome $\mathrm{P} 450$ enzyme 25-hydroxyvitamin D-1 $\alpha$-hydroxlase (CYP27B1) hydroxylates 25-hydroxyvitamin D (25D) to synthesise the biologically active 1,25D (Omdahl et al. 2002). Overproduction of $1,25 \mathrm{D}$ by the kidney is subject to regulation by a separate cytochrome $\mathrm{P} 450$ enzyme, 25-hydroxyvitamin D-24-hydroxylase (CYP24), which, through side chain hydroxylation 
reactions, inactivates 1,25D (Omdahl et al. 2002). The relative importance of the activity of CYP27B1 and CYP24 in the regulation of serum 1,25D remains unclear.

Critical to an understanding of the control of $1,25 \mathrm{D}$ production in the kidney is a molecular appreciation of the regulatory signals that underlie expression of the genes for CYP27B1, GYP24 and vitamin $\mathrm{D}$ receptor (VDR). In this regard, it is important to quantify the steady state levels of mRNA for these genes expressed in kidney and particularly in response to different hormone and dietary factors. However, since the CYP27B1 mRNA is a low abundance mRNA and cannot be successfully quantified by Northern blot or RNase protection analyses, the development of a sensitive and quantitative assay for this and other mRNAs has been undertaken in this current study.

Total mRNA has been isolated from rat kidney and specific mRNAs quantified using a real-time RT-PGR protocol. We have successfully demonstrated the high reproducibility of this method in kidney tissue and the ability to detect amounts of mRNA as low as a few hundred copies of target sequence. Analyses of duplicated samples on different days confirm the accuracy and efficiency of the protocol. This procedure will be useful for those interested in the regulation of these and other genes in whole tissue samples. Increased levels of dietary calcium in rats resulted in a reduction in serum 1,25D and renal CYP27B1 mRNA, while renal CYP24 mRNA was increased. Statistical analysis indicated that both CYP27B1 mRNA and CYP24 mRNA contributed equally to determining serum 1,25D.

\section{Materials and methods}

\section{Animals}

Female Sprague-Dawley rats of 4 months of age $(n=24)$ were obtained from the Gilles Plains Animal Resource Centre (Gilles Plains, SA, Australia) and were housed at $24^{\circ} \mathrm{C}$ with a $12-\mathrm{h}$ light/darkness cycle. The rats were fed $40 \mathrm{~g}$ per day for 2 months of the AIN-76 semi-synthetic diet (American Institute of Nutrition 1977, 1980) containing $0.05 \%, 0.2 \%, 0.4 \%$ or $1 \%$ calcium. The Institute of Medical and Veterinary Science Animal Ethics Committee approved all animal procedures.

\section{Biochemical analyses}

Serum $1,25 \mathrm{D}$ was measured by a ${ }^{125}$ I radioimmunoassay (RIA) (Immunodiagnostic Systems Ltd, Boldon, Tyne and Wear, UK). Serum parathyroid hormone $(\mathrm{PTH})$ was measured using a ratspecific, two-site immunoradiometric assay (IRMA) (Immutopics, Inc., San Clemente, CA, USA).

\section{PCR standards}

The full-length cDNAs for CYP27B1 (St-Arnaud et al. 1997, obtained from R St-Arnaud), CYP24 (Ohyama et al. 1991, obtained from J Omdahl) and glyceraldehyde 3-phosphate dehydrogenase (GAPDH) (Fort et al. 1985, Tso et al. 1985) cDNA were inserted into pBluescript 2 SK vector. A 466 bp cDNA for VDR (Burmester et al. 1988, Kamei et al. 1995) encompassing the amplicon region for the real-time PCR was generated from reverse transcribing rat kidney mRNA with Moloney Murine Leukemia Virus (MMLV) reverse transcriptase (Invitrogen, CA, USA) according to the manufacturer's instructions. The cDNA was then PGR amplified using forward and reverse primers (forward: 5'-gattgccgcatcaccaaggac- $3^{\prime}$; reverse: $5^{\prime}$-gaggagacaggtccagagtca- ${ }^{\prime}$ ) and Amplitaq Gold DNA polymerase (Perkin-Elmer (PE) Applied Biosciences, Foster City, CA USA).

\section{Total RNA extraction and cDNA synthesis}

Kidneys were removed from carcasses of rats and immediately frozen in liquid nitrogen. Total RNA was isolated in duplicate from kidney tissues. The extraction of total RNA from the homogenised tissue lysates was based on a phenol/chloroform extraction method modified from Chomczynski and Sacchi (1987) as described by Davey et al. (2000). Briefly, tissues were homogenised in $10 \mathrm{ml}$ of a solution containing $4 \mathrm{M}$ guanidine isothiocyanate. Tissue lysate was mixed with $0 \cdot 1 \mathrm{M}$ citrate buffer saturated phenol, pH 4.3, $2 \mathrm{M}$ sodium acetate and 24:1 chloroform/isoamyl alcohol. After centrifuging, the aqueous phase was removed and mixed with 1 volume isopropanol and frozen at $-70{ }^{\circ} \mathrm{C}$. The samples were then centrifuged to recover the RNA, redissolved in TE buffer, mixed with 3 volumes $4 \mathrm{M}$ sodium acetate and frozen at $-70{ }^{\circ} \mathrm{C}$. The thawed samples were then centrifuged to recover the pure RNA and washed with $500 \mu \mathrm{l}$ $70 \%$ ethanol, before re-centrifugation. The dried 
Table 1 Fluorogenic probe and primer sets

\begin{tabular}{|c|c|c|c|c|}
\hline & $\begin{array}{l}\text { Primer/ } \\
\text { probe }\end{array}$ & Sequence $5^{\prime} \rightarrow 3^{\prime}$ & $\begin{array}{l}\text { Sequence } \\
\text { number }\end{array}$ & $\begin{array}{l}\text { Amplicon } \\
\text { (bp) }\end{array}$ \\
\hline \multicolumn{5}{|l|}{ Gene } \\
\hline \multirow[t]{3}{*}{ CYP27B1 } & $\mathrm{F}$ & GAGATCACAGGCGCTGTGAAC & $1030-1050$ & \multirow{3}{*}{107} \\
\hline & $\mathrm{R}$ & TCCAACATCAACACTTCTTTGATCA & $1138-1114$ & \\
\hline & $\operatorname{Pr}$ & 6FAM-TGTCCCAGCTACCCCTGCTAAAGGCT-TAMRA & $1087-1112$ & \\
\hline \multirow[t]{3}{*}{ CYP24 } & $\mathrm{F}$ & TGGATGAGCTGTGCGATGA & $1333-1351$ & \multirow[t]{3}{*}{75} \\
\hline & $\mathrm{R}$ & TGCTTTCAAAGGACCACTTGTTC & $1407-1385$ & \\
\hline & $\operatorname{Pr}$ & 6FAM-CGAGGCCGCATCCCAGACCTG-TAMRA & $1353-1373$ & \\
\hline \multirow[t]{3}{*}{ VDR } & $\mathrm{F}$ & TGACCCCACCTACGCTGACT & 523-542 & \multirow[t]{3}{*}{79} \\
\hline & $\mathrm{R}$ & CCTTGGAGAATAGCTCCCTGTACT & $599-576$ & \\
\hline & $\operatorname{Pr}$ & 6FAM-ACTTCCGGCCTCCAGTTCGTATGGAC-TAMRA & $549-572$ & \\
\hline \multirow[t]{3}{*}{ GAPDH } & $\mathrm{F}$ & TGCACCACCAACTGCTTA & $519-536$ & \multirow[t]{3}{*}{177} \\
\hline & $\mathrm{R}$ & GGATGCAGGGATGATGTT & $589-572$ & \\
\hline & $\operatorname{Pr}$ & VIC-CAGAAGACTGTGGATGGCCCCTC-TAMRA & $556-578$ & \\
\hline
\end{tabular}

All primer (forward $(F)$ and reverse $(R)$ ) and probe $(\mathrm{Pr})$ sets were specific for rat cDNA sequence and designed to span an intronic sequence. Exon/intron boundaries are shown as underlined bases. For GAPDH, the boundary occurs between the forward primer and the probe. Fluorogenic probes are FAM- or VIC-labelled at the $5^{\prime}$ end and TAMRA-labelled at the $3^{\prime}$ end.

RNA pellet was finally dissolved in TE buffer and stored at $-70{ }^{\circ} \mathrm{C}$. To generate first strand cDNA, total RNA ( $5 \mu \mathrm{g}$ ) from each tissue sample was primed with a random hexamer primer (Geneworks, Adelaide, Australia) and reversetranscribed at $37^{\circ} \mathrm{C}$ for $1 \mathrm{~h}$ using MMLV reverse transcriptase (Invitrogen) according to the manufacturer's instructions, and stored at $-70^{\circ} \mathrm{C}$.

\section{Primers and probes}

The sequence of the primers and fluorogenic probes, based on published sequences for rat CYP27B1 (St-Arnaud et al. 1997), CYP24 (Ohyama et al. 1991), VDR (Burmester et al. 1988, Kamei et al. 1995) and GAPDH (Fort et al. 1985, Tso et al. 1985), were designed using Primer Express 1.5 software (PE Applied Biosystems) (Table 1). The fluorogenic probes were synthesised by PE Applied Biosystems. The primers were synthesised by Geneworks. All primer sets were designed to span an intron (see Table 1) thus avoiding a problem with contaminating genomic DNA.

\section{Real-time PCR reaction conditions}

All PGR reactions were carried out in a final volume of $25 \mu \mathrm{l}$ and were performed in duplicate for each cDNA sample in the ABI PRISM 7700 Sequence Detection System (PE Applied Biosystems) according to the manufacturer's proto- col. The optimised reaction mix consisted of Universal Master Mix (PE Applied Biosystems), $200 \mathrm{nM}$ fluorogenic probe and $300 \mathrm{nM}$ of each specific forward and reverse primer. The PCR protocol was $50{ }^{\circ} \mathrm{C}$ for $2 \mathrm{~min}$ and $95^{\circ} \mathrm{C}$ for $10 \mathrm{~min}$, which was followed by 45 cycles at $95{ }^{\circ} \mathrm{C}$ for $15 \mathrm{~s}$ and at $60{ }^{\circ} \mathrm{C}$ for $1 \mathrm{~min}$.

\section{Data expression}

For each assay, a standard curve was obtained by analysing a dilution series of plasmid cDNA standards for CYP27B1, CYP24, VDR or GAPDH. The concentration of plasmid cDNA for each target mRNA species was estimated by measuring the $\mathrm{A}_{260}$ in triplicate, using a spectrophotometer (Beckman DU153, CA, USA). The copy number was calculated using the following formula:

$$
\text { copies } / \mathrm{ml}=6.023 \times 10^{23} \times \frac{\mathrm{C} \times \mathrm{A}_{260}}{\mathrm{MWt}}
$$

where $\mathrm{G}=50 \mu \mathrm{g} / \mathrm{ml}$ for double stranded (ds) DNA and $\mathrm{MWt}=\mathrm{cDNA}$ molecular weight (base pairs $\times 6.5 \times 10^{2}$ Daltons).

After completion of the PCR amplification, data were analysed with Sequence Detector 1.7 software (PE Applied Biosystems). The threshold cycle $\left(\mathrm{G}_{\mathrm{T}}\right)$ values generated from the amplification of plasmid cDNA samples were plotted against the log of cDNA copy numbers to create a linear standard 
curve. The real-time PCR analysis of the same series of cDNA standard dilutions was repeated one to two weeks later. A measurement of the mRNA copy numbers in an experimental sample for each gene of interest was determined by obtaining the $\mathrm{C}_{\mathrm{T}}$ values for each target cDNA sequence in an experimental sample and interpolating the cDNA copy number from the plasmid cDNA standard curve. The determination of mRNA copy numbers assumed that reverse transcription of mRNA to cDNA was $100 \%$ efficient.

\section{Statistical analysis}

Efficiency of real-time RT-PCR was tested by the 'least squares' method of linear regression statistical analysis. Amplification efficiency in the plasmid cDNA standard curves was tested by comparing the line-of-best-fit with a theoretical line representing the maximum amplification efficiency. A slope of -3.32 is the theoretical maximal slope obtained by regression analysis of a PCR reaction of optimal efficiency. Linear regression analysis was used to determine whether there was a difference between $\mathrm{C}_{\mathrm{T}}$ values from a theoretically maximal amplification and $\mathrm{C}_{\mathrm{T}}$ values obtained in the plasmid cDNA amplification reactions performed. The same statistical procedure was used to determine the mRNA amplification efficiency. Linear regression analysis was used to test the reproducibility of real-time RT-PCR by comparing the line-of-unity with the line-of-best-fit for the X-Y scatter plot of copy number values obtained from two separate RNA extractions and real-time RT-PCR assays.

\section{Results}

\section{Standard curves}

Standard curves were generated from serial dilutions of plasmid cDNA standards for CYP27B1, CYP24, VDR and GAPDH. Plasmid cDNA for each species was serially diluted twofold to span the range of predicted $\mathrm{C}_{\mathrm{T}}$ values that would be obtained from experimental samples. Standard curves for each plasmid cDNA standard demonstrated linearity over the complete range of dilution series with correlation coefficients of 0.99 (Fig. 1). The efficiency of the amplification of plasmid cDNA standard was within $10 \%$ of the theoretical optimum slope of -3.32 for each PCR amplification. The reaction efficiency for CYP24 was 100\%, while the efficiencies for CYP27B1, VDR and GAPDH were 96\%, 93\%, and 90\% respectively.

From the standard curves it can be seen that the maximum $\mathrm{C}_{\mathrm{T}}$ value detected was $37 \cdot 4 \pm 0 \cdot 6$, for an estimated $1.5 \times 10^{2}$ copies of VDR cDNA (Table 2). No amplification was observed in the no-template controls (NTG) reactions up to a maximum of 45 cycles $\left(\mathrm{C}_{\mathrm{T}}>45\right)$. The most concentrated and the most dilute cDNA sample of each mRNA under investigation provided $\mathrm{C}_{\mathrm{T}}$ values, spanning the range of $\mathrm{C}_{\mathrm{T}}$ values expected for unknown samples.

The analysis of plasmid cDNA standards by real-time PCR, used for establishment of the standard curves, was repeated one to two weeks later. Comparisons of the $\mathrm{C}_{\mathrm{T}}$ values obtained from the two separate PCR reactions on serially diluted plasmid cDNA for CYP27B1, CYP24, VDR and GAPDH showed a high degree of reproducibility when analysed by the linear regression analysis (data not shown). The coefficient of variation (CV) for the comparisons between the two assays was less than 5\% for CYP27B1, VDR and GAPDH, whilst CYP24 had a CV of $5.5 \%$ indicating the highly reproducible nature of the analysis. However, when the mRNA copy numbers, estimated from the interpolation of $\mathrm{C}_{\mathrm{T}}$ values from each of the two individual standard curves, were plotted against each other, the slope and intercept for each gene of interest were statistically different from the line-of-unity. The average difference in mRNA copy numbers determined from each standard curve was 20\% for CYP27B1, while for CYP24, VDR and GAPDH there was a 13\%,36\% and 20\% difference respectively (data not shown).

\section{Reproducibility of mRNA analysis by real-time RT-PCR detection}

The reproducibility of the extraction of total RNA from kidney tissue and the quantification of target mRNA by real-time RT-PCR was tested by comparing duplicate analyses of total RNA extractions. There was a high degree of reproducibility between the copy numbers of mRNA derived from the two separate PGR reactions in all target sequences examined (Fig. 2). For CYP27B1, CYP24 and VDR, the coefficient of determination was greater than $0 \cdot 90$. For GAPDH, the coefficient of determination was lower at $0 \cdot 63$. The lines-ofbest-fit for each target gene were statistically the 

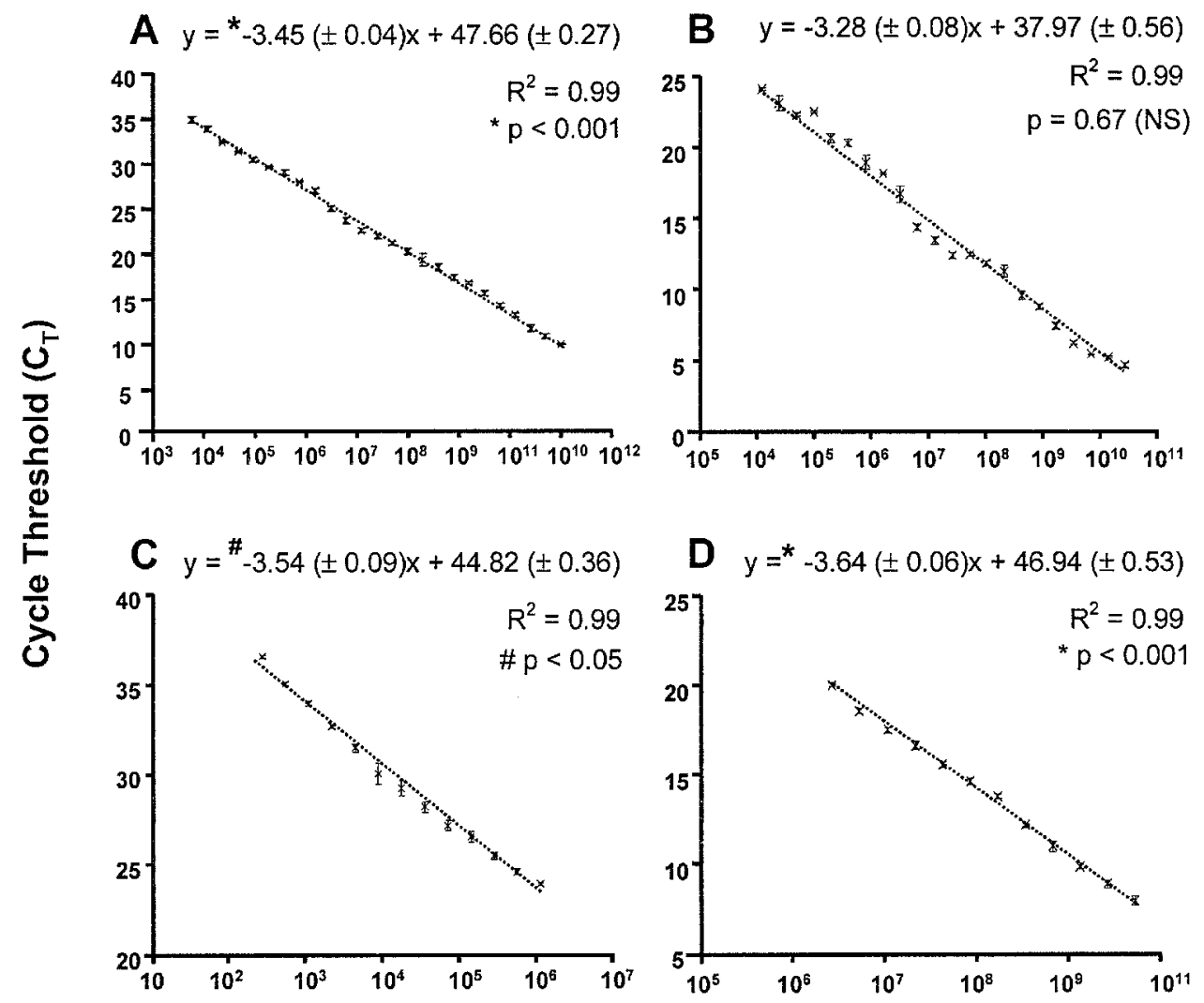

\section{cDNA Copy Number}

Figure 1 Standard curves of (A) CYP27B1, (B) CYP24, (C) VDR and (D) GAPDH cDNA. CDNA was serially diluted 1:2 before amplification with the appropriate primers and probe. Each sample was assayed in duplicate and re-assayed one week later. The standard curve is a product of both assays. The equation for the line-of-best-fit, $y=$ slope $( \pm$ S.D. $) x+$ intercept $( \pm$ S.D. $)$ and the coefficient of determination $\left(R^{2}\right)$ are shown for each standard curve. ${ }^{*} P<0.001$ vs theoretical slope, ${ }^{\#} P<0.05$ vs theoretical standard curve slope for maximum amplification efficiency. NS, not significant.

same as the line-of-unity (data not shown). The reproducibility of $\mathrm{mRNA}$ analysis by real-time RT-PCR, expressed as the coefficient of variation, was $16 \cdot 4 \%$ for CYP27B1 at a level of $6 \times 10^{6}$ copies/ $\mu \mathrm{g}$ total RNA, $12 \cdot 5 \%$ for CYP24 at a level of $2 \times 10^{6}$ copies $/ \mu \mathrm{g}$ total RNA, $19 \cdot 5 \%$ for VDR at a level of $2 \times 10^{8}$ copies $/ \mu \mathrm{g}$ total RNA and $30 \cdot 5 \%$ for GAPDH at a level of $1 \times 10^{9}$ copies $/ \mu g$ total RNA.

\section{Accuracy of the estimation of mRNA levels by reverse-transcription and real-time PCR amplification}

The accuracy of the estimation of mRNA levels by reverse transcription and PCR amplification was assessed using rat kidney total RNA. Purified total RNA was serially diluted twofold, commencing from $5 \mu \mathrm{g}$ total RNA for each sample. Each dilution was then reverse-transcribed to cDNA and target cDNA sequences were amplified by real-time PCR amplification using an appropriate primer and probe set (Table 3). The coefficient of determination for each line-of-best-fit was greater than 0.95. The degree of efficiency of the amplification was not statistically different from the theoretical maximal amplification efficiency for any of the mRNA species tested, indicating that the accuracy for estimating the concentration of each of the mRNA species was greater than $95 \%$. 
Table 2 Sensitivity of fluorogenic probe for detection. Results show amplification of rat plasmid cDNA standards. The no template control (NTC) was allotted a value of $>45$ when no amplification was detected in the $45^{\text {th }}$ cycle of the PCR reaction

\section{Range of copies detected}

\section{Fluorogenic}

probe

$\begin{array}{ll}\text { CYP27B1 } & 6.2 \times 10^{3}-1.0 \times 10^{11} \\ \text { CYP24 } & 1.3 \times 10^{3}-2.7 \times 10^{10} \\ \text { VDR } & 1.5 \times 10^{2}-1.2 \times 10^{6} \\ \text { GAPDH } & 2.8 \times 10^{7}-5.8 \times 10^{10}\end{array}$

Range of $\mathrm{C}_{\mathrm{T}}$ values detected

NTC

$\left(\mathrm{C}_{\mathrm{T}}\right)$

$$
\begin{array}{ll}
34 \cdot 2 \pm 0 \cdot 01-9 \cdot 7 \pm 0.05 & >45 \\
24 \cdot 1 \pm 0 \cdot 05-5 \cdot 0 \pm 0.3 & >45 \\
37 \cdot 4 \pm 0 \cdot 6-23 \cdot 8 \pm 0.06 & >45 \\
20 \cdot 0 \pm 0 \cdot 2-8 \cdot 0 \pm 0 \cdot 06 & >45
\end{array}
$$

$\mathrm{C}_{\mathrm{T}}$, threshold cycle.

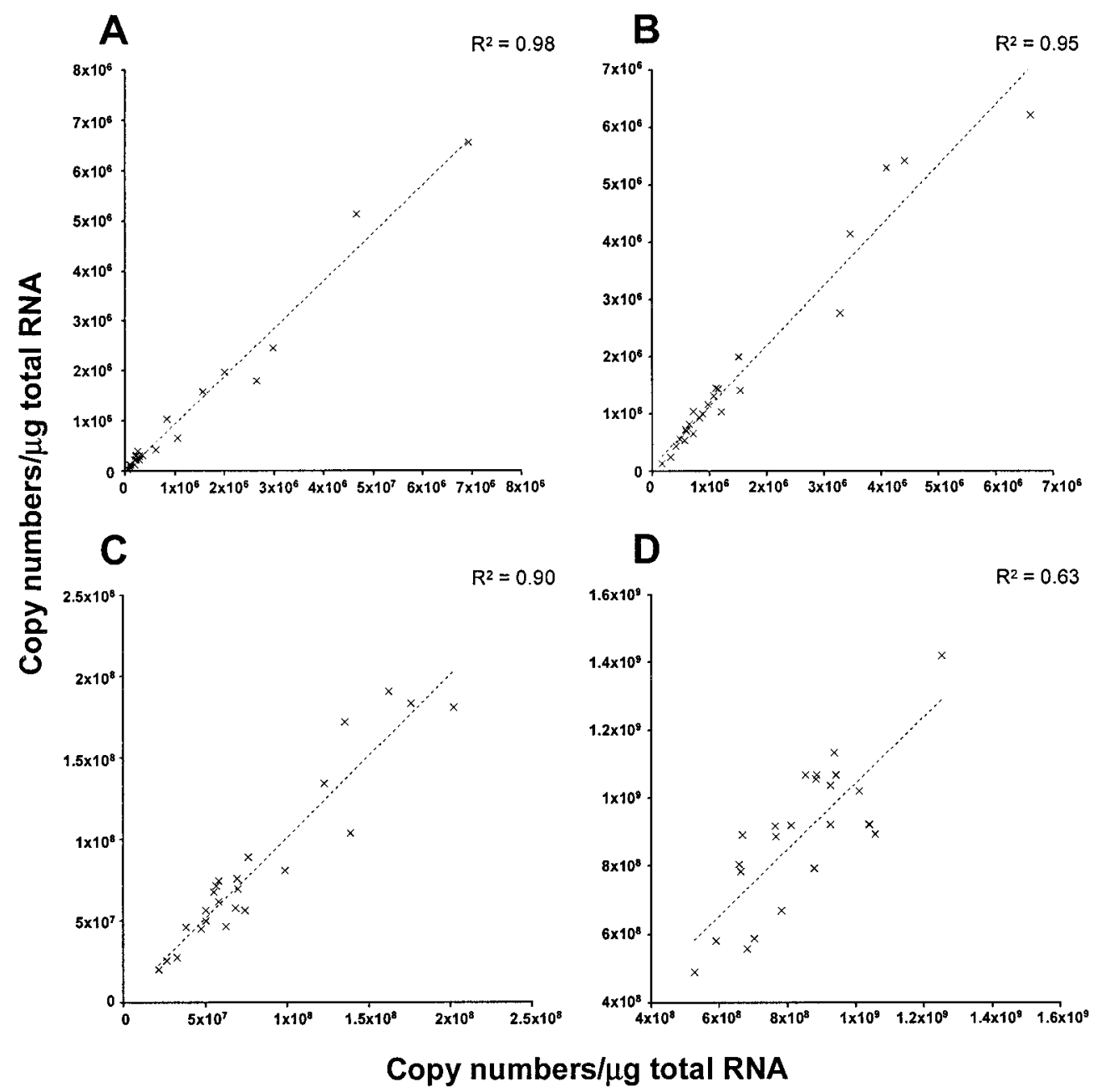

Figure 2 Reproducibility of the copy numbers from kidney samples for (A) CYP27B1, (B) CYP24, (C) VDR and (D) GAPDH. The horizontal axis shows the results of run 1 and the vertical axis the results of run 2 . The coefficient of determination $\left(R^{2}\right)$ is shown for each of the regression analyses. 
Table 3 Efficiency of mRNA amplification of kidney samples

\begin{tabular}{|c|c|c|}
\hline & Equation & $\begin{array}{l}\text { Coefficient of } \\
\text { determination }\end{array}$ \\
\hline $\begin{array}{l}\text { Gene } \\
\text { CYP27B1 } \\
\text { CYP24 } \\
\text { VDR } \\
\text { GAPDH }\end{array}$ & $\begin{array}{l}y=-3.21( \pm 0.14) x+32.7( \pm 0.09) \\
y=-3.23( \pm 0.17) x+25.4( \pm 0.07) \\
y=-3.56( \pm 0.10) x+21.4( \pm 0.05) \\
y=-3.57( \pm 0.29) x+17.9( \pm 0.15)\end{array}$ & $\begin{array}{l}R^{2}=0.99 \\
R^{2}=0.99 \\
R^{2}=0.95 \\
R^{2}=0.97\end{array}$ \\
\hline
\end{tabular}

Table 4 Serum 1,25D and PTH in rats fed different dietary calcium concentrations. Values are means ( \pm S.E.M.), $n=24$

\begin{tabular}{|c|c|c|c|c|}
\hline & $0.05 \% \mathrm{Ca}$ & $0.2 \% \mathrm{Ca}$ & $0.4 \% \mathrm{Ca}$ & $1 \% \mathrm{Ca}$ \\
\hline $\begin{array}{l}1,25 \mathrm{D}(\mathrm{pmol} / \mathrm{l}) \\
\text { PTH (pmol/l) }\end{array}$ & $\begin{array}{c}188.8( \pm 20 \cdot 3) \\
14.2( \pm 2 \cdot 8)\end{array}$ & $\begin{array}{c}133.6( \pm 30.9) \\
12.7( \pm 1.5)\end{array}$ & $\begin{array}{l}66 \cdot 2( \pm 15 \cdot 7)^{\star} \\
14 \cdot 1( \pm 1 \cdot 8)\end{array}$ & $\begin{array}{c}10.6( \pm 0.97)^{\star \#} \\
7.3( \pm 1.3)^{\dagger}\end{array}$ \\
\hline
\end{tabular}

\section{Assessment of GAPDH mRNA as the referent for mRNA quantification}

In the kidney, the levels of GAPDH mRNA detected in different dietary groups were constant, with no statistical difference found between levels of GAPDH in any of the samples (data not shown). For this reason, the use of GAPDH mRNA in the kidney appears to be reasonable for use as a referent for the mRNA levels of the genes of interest.

\section{Regulation of serum 1,25D, PTH, kidney CYP27B1, CYP24 and VDR mRNA levels by dietary calcium}

The levels of serum 1,25D and PTH fell with an increase in dietary calcium concentration (Table 4). The levels of GYP27B1 mRNA in the animals fed $0.05 \%$ calcium were significantly higher than those in animals fed higher calcium concentrations in their diet $(P<0.01)$ (Fig. 3A). Conversely, CYP24 mRNA levels were significantly higher in the animals fed $1 \%$ calcium when compared with the animals fed lower calcium concentrations in their diet $(P<0.01)$ (Fig. 3A). Similarly, VDR mRNA levels were significantly higher in animals fed $1 \%$ calcium $(P<0.01)$ (Fig. 3B). In addition, the levels of VDR mRNA positively correlated with the levels of CYP24 mRNA $\left(\mathrm{R}^{2}=0.71, P<0.001\right)$ (data not shown).

\section{Determinants of serum 1,25D levels}

Serum 1,25D levels correlated positively with kidney CYP27B1 mRNA levels $\left(\mathrm{R}^{2}=0 \cdot 32, P<0 \cdot 01\right)$ and negatively with kidney CYP24 mRNA levels $\left(\mathrm{R}^{2}=0 \cdot 30, P<0 \cdot 01\right)$. In a multiple linear regression, both CYP27B1 and CYP24 were significant determinants of serum 1,25D levels (Multiple $\mathrm{R}^{2}=0 \cdot 70$, $P<0.001)$ (Table 5). No significant correlation between serum PTH and either CYP27B1 or CYP24 mRNA was identified $(P=0 \cdot 69)$.

\section{Discussion}

In this study we have optimised the experimental protocol for real-time RT-PGR for the quantification of CYP27B1, CYP24 and VDR mRNAs isolated from rat kidney tissue. This report demonstrates that quantification of low abundance mRNA can be achieved from kidney tissue with high precision and accuracy by real-time RT-PCR with fluorogenic probes. This system accurately determines low levels of target mRNA expression. The fluorogenic probes were able to readily and reliably detect as few as 150 copies of target cDNA per reaction. The sensitivity of real-time RT-PCR overcomes the shortfalls of other less sensitive methods, such as Northern blot analysis or ribonuclease protection assay, particularly with respect to the analysis of low abundance mRNAs such as CYP27B1 and CYP24 mRNA. 

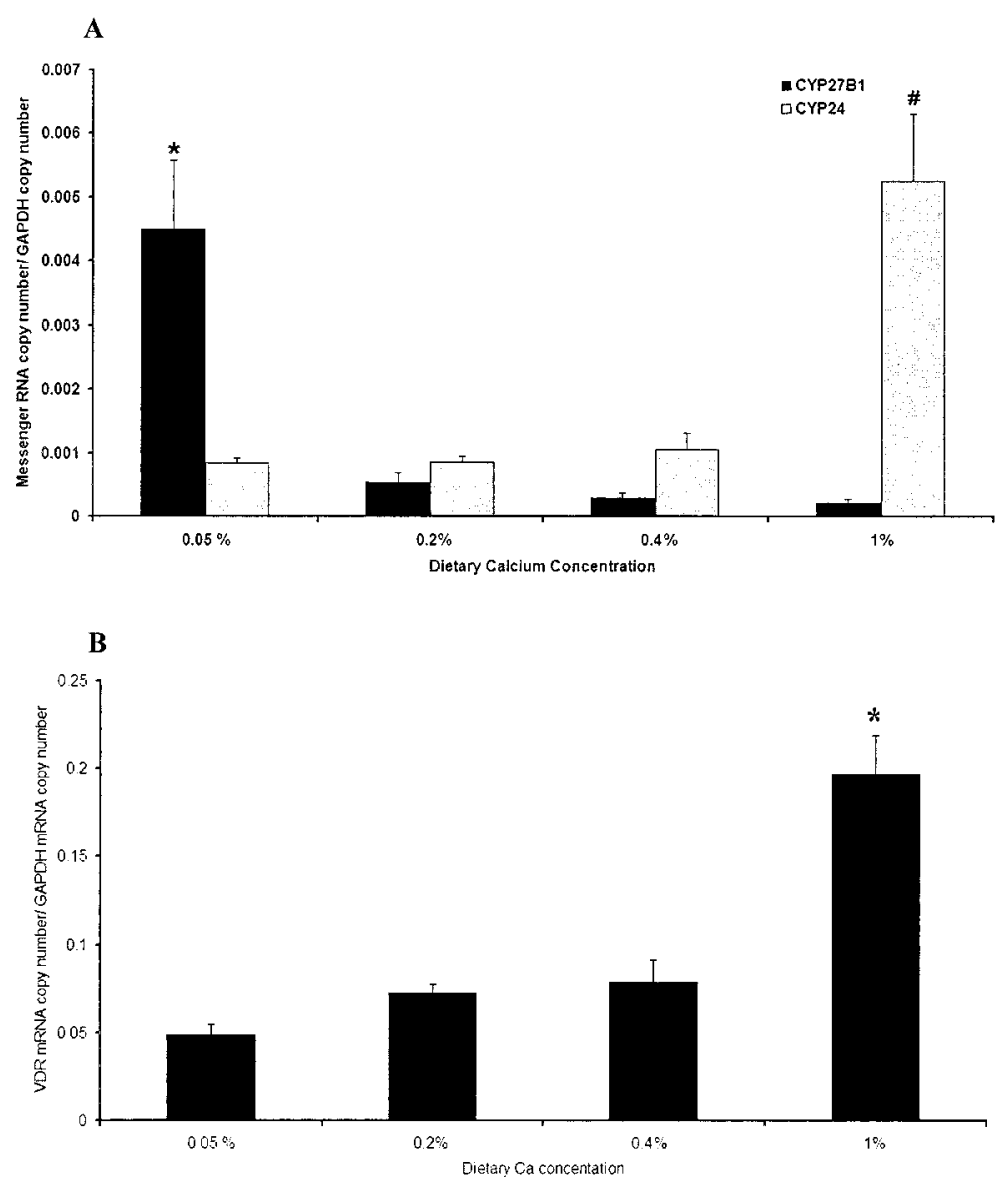

Figure 3 (A) Expression of kidney CYP27B1 (black bars) and CYP24 (grey bars) mRNA (copy number/GAPDH mRNA copy number) in each dietary calcium treatment group. Values are means \pm S.E.M. $(n=6)$. ${ }^{*} P<0.01$ vs $0.2 \% \mathrm{Ca}, 0.4 \% \mathrm{Ca}$ and $1 \% \mathrm{Ca} .{ }^{*} P<0.01$ vs $0.05 \% \mathrm{Ca}$, $0.2 \% \mathrm{Ca}$ and $0.4 \% \mathrm{Ca}$. (B) Expression of kidney VDR mRNA (copy number/GAPDH mRNA copy number) in each dietary calcium treatment group. Values are means \pm S.E.M. $(n=6)$. ${ }^{*} P<0.01$ vs $0.05 \%$ $\mathrm{Ca}, 0.2 \% \mathrm{Ca}$ and $0.4 \% \mathrm{Ca}$.

Linear amplification was detected over a large concentration range, up to $2 \times 10^{7}$-fold in the case of CYP27B1 plasmid cDNA. The $\mathrm{C}_{\mathrm{T}}$ values of the plasmid cDNA standards generated on different occasions showed a high reproducibility throughout the entire concentration range tested. However, when the mRNA copy number for a single unknown sample was derived from an individual standard curve generated at the time of analysis, there was a significant difference in the estimated amounts of copy numbers. This finding indicates that even though the two standard curves demonstrate a high degree of reproducibility with regard to the $\mathrm{G}_{\mathrm{T}}$ values, a statistically insignificant shift of the standard curve can cause a substantial difference in the quantity of cDNA estimated from the standard curves. Thus, the reproducibility of the analysis is increased when unknown samples are quantified from a single standard curve calculated from the average of at least two standard curves obtained through the amplification of a range of plasmid cDNA standards.

Duplicates of kidney mRNA extraction, reverse transcription and PCR reaction exhibited a high degree of reproducibility. No statistical difference could be determined between the $\mathrm{C}_{\mathrm{T}}$ values obtained from two separate PGR reactions. While no direct measurement was made to determine the 
Table 5 Single and multiple linear regression equations for renal CYP27B1 and CYP24 mRNA levels (corrected for GAPDH) as determinants of serum 1,25D. $n=24$

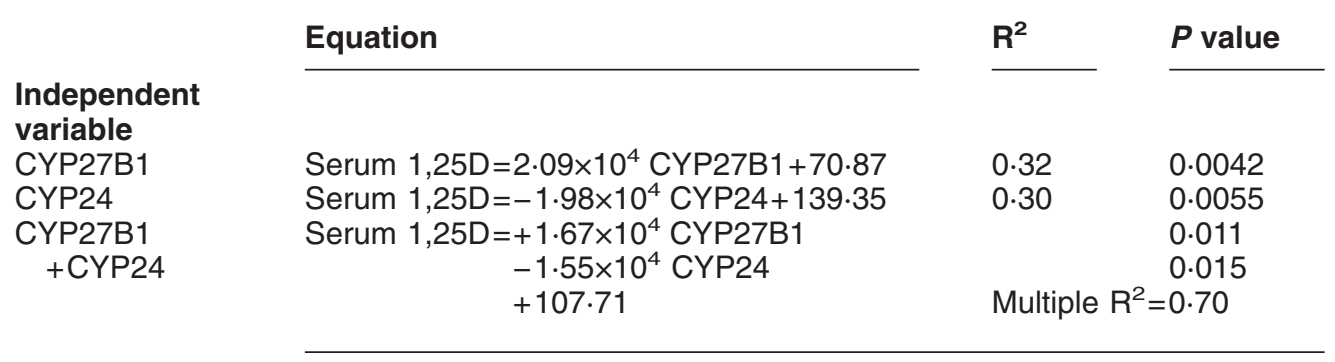

effectiveness of the first-strand synthesis of cDNA from mRNA, we can assume from these data that the efficiency of the reverse-transcription reaction with this protocol is constant for all samples. The reproducibility and high amplification efficiency of the reverse-transcribed $\mathrm{mRNA}$ indicate that the quantitative procedure of real-time RT-PCR is unaffected by the use of the phenol/chloroform method to purify total RNA from kidney tissues, or by subsequent reverse-transcription of mRNA.

The use of an endogenous referent to control for analytical variation is important for normalisation of analyses from different animals. Since the $\mathrm{C}_{\mathrm{T}}$ values and mRNA levels obtained for GAPDH in the kidney from each dietary treatment were statistically similar, the use of GAPDH as a referent is appropriate. There have, however, been a number of reports suggesting that GAPDH mRNA expression is regulated by various physiological challenges (Bustin et al. 1999, Oliveira et al. 1999, Thellin et al. 1999). For this reason, the use of total RNA as a referent has been recommended by a number of researchers (Bustin 2002, Ogunkolade et al. 2002). While total RNA referent does not correct for the amount of cDNA loaded into each PGR tube, a high degree of reproducibility between two separate PCR runs found in the current study suggests that total RNA could be used as a satisfactory referent.

$1,25 \mathrm{D}$ is essential for the stimulation of intestinal calcium absorption (Li et al. 2001, Panda et al. 2001). In the current study, serum $1,25 \mathrm{D}$ levels fell with increasing dietary calcium and correlated positively with kidney CYP27B1 mRNA levels and negatively with kidney CYP24 mRNA levels. Multiple linear regression analysis indicated that the fall in serum $1,25 \mathrm{D}$ levels was due to both a reduction in the synthesis of $1,25 \mathrm{D}$ by kidney CYP27B1 and to an increase in the catabolism of
1,25D by kidney CYP24. This suggests that GYP27B1 and GYP24 are equally important in the regulation of the metabolism of vitamin $\mathrm{D}$ in the kidney. In this study, CYP24 mRNA levels correlated positively with VDR mRNA levels. A concomitant rise in kidney VDR and CYP24 mRNA levels has been indicated previously by Johnson et al. (1995). They showed that mRNA and protein levels of renal VDR and CYP24 were both high in 18-month-old female Fischer 344 rats and were both low in 6-month-old or younger rats. Liganded VDR can directly regulate CYP24 gene expression by binding to one of two distinct vitamin $\mathrm{D}$ response elements which are located in the promoter region of the CYP24 gene (Ohyama et al. 1994, Chen \& DeLuca 1995, Dwivedi et al. 2000).

Identification of factors responsible for the regulation of renal CYP27B1 and CYP24 gene transcription is of considerable interest. $\mathrm{PTH}$ is an important stimulator of CYP27B1 gene transcription (Murayama et al. 1999). However, in this study when adult rats were fed a vitamin D-replete diet, no significant correlation was found between PTH and renal GYP27B1 mRNA levels. These data support the proposal of Shinki et al. (1999) that the transcription of CYP27B1 in vivo is upregulated by PTH only in hypocalcaemic animals and not during normocalcaemia. In the current study, when adult animals were fed a vitamin D-replete diet with varying, but adequate, levels of calcium, normal blood calcium levels were maintained. Shinki et al. (1999) proposed that, under these conditions, calcitonin is the major regulator of CYP27B1 mRNA expression. A direct effect of calcium on the expression of CYP27B1 mRNA cannot, however, be ruled out (Bland et al. 1999). The marked increase in the levels of CYP24 mRNA found in animals fed a $1 \%$ calcium diet is likely to be due to the decrease in PTH levels, since 
it has been reported that PTH promotes the degradation of CYP24 mRNA (Zierold et al. 2001).

In summary, when studying the metabolism of vitamin $\mathrm{D}$ in the kidney, the regulation of CYP27B1 activity should not be the only focus of investigation. Equal importance should be attributed to the effects of the catabolising enzyme, CYP24. Since both enzymes appear to be regulated by factors such as PTH, calcium and calcitonin, future research should focus on the mechanisms by which these factors control vitamin $\mathrm{D}$ synthesis and catabolism under different physiological conditions.

\section{References}

Bieri JG, Stoewsand GS, Briggs GM, Phillips RW, Woodward JC \& Knapka JJ 1977 Report of the American Institute of Nutrition ad hoc committee on standards for nutritional studies. Fournal of Nutrition 107 1340-1348.

Bieri JG 1980 Second Report of the American Institute of Nutrition ad hoc committee on standards for nutritional studies. Fournal of Nutrition 1101726.

Bland R, Walker EA, Hughes SV, Stewart PM \& Hewison M 1999 Constitutive expression of 25-hydroxyvitamin D3-1 alphahydroxylase in a transformed human proximal tubule cell line: evidence for direct regulation of vitamin $\mathrm{D}$ metabolism by calcium. Endocrinology 140 2027-2034.

Burmester JK, Maeda N \& DeLuca HF 1988 Isolation and expression of rat 1,25-dihydroxyvitamin D3 receptor cDNA. PNAS 85 1005-1009.

Bustin SA 2002 Quantification of mRNA using real-time reverse transcription PCR (RT-PCR): trends and problems. Fournal of Molecular Endocrinology 29 23-39.

Bustin SA, Gyselman VG, Williams NS \& Dorudi S 1999 Detection of cytokeratins 19/20 and guanylyl cyclase C in peripheral blood of colorectal cancer patients. British Fournal of Cancer $\mathbf{7 9}$ $1813-1820$

Chen KS \& DeLuca HF 1995 Cloning of the human 1 alpha,25dihydroxyvitamin D-3 24-hydroxylase gene promoter and identification of two vitamin D-responsive elements. Biochimica et Biophysica Acta 1263 1-9.

Chomczynski P \& Sacchi N 1987 Single-step method of RNA isolation by acid guanidinium thiocyanate-phenol-chloroform extraction. Analytical Biochemistry 162 156-159.

Davey RA, Hahn CN, May BK \& Morris HA 2000 Osteoblast gene expression in rat long bones: effects of ovariectomy and dihydrotestosterone on mRNA levels. Calcified Tissue International $\mathbf{6 7}$ 75-79.

Dwived, PP, Omdahl JL, Kola I, Hume DA \& May BK 2000 Regulation of rat cytochrome P450C24 (CYP24) gene expression. Evidence for functional cooperation of Ras-activated Ets transcription factors with the vitamin $\mathrm{D}$ receptor in 1,25-dihydroxyvitamin D(3)-mediated induction. Fournal of Biological Chemistry 275 47-55.

Fort P, Marty L, Piechaczyk M, el Sabrouty S, Dani C, Jeanteur P \& Blanchard JM 1985 Various rat adult tissues express only one major mRNA species from the glyceraldehyde-3-phosphatedehydrogenase multigenic family. Nucleic Acids Research $\mathbf{1 3}$ 1431-1442.

Johnson JA, Beckman MJ, Pansini-Porta A, Christakos S, Bruns ME, Beitz DC, Horst RL \& Reinhardt TA 1995 Age and gender effects on 1,25-dihydroxyvitamin D3-regulated gene expression. Experimental Gerontology 30 631-643.

Kamei Y, Kawada T, Fukuwatari T, Ono T, Kato S \& Sugimoto E 1995 Cloning and sequencing of the gene encoding the mouse vitamin D receptor. Gene 152 281-282.

Li YC, Bolt MJ, Cao LP \& Sitrin MD 2001 Effects of vitamin D receptor inactivation on the expression of calbindins and calcium metabolism. American Fournal of Physiological and Endocrinological Metabolism 281 E558-E564.

Murayama A, Takeyama K, Kitanaka S, Kodera Y, Kawaguchi Y, Hosoya T \& Kato S 1999 Positive and negative regulations of the renal 25-hydroxyvitamin D3 1 alpha-hydroxylase gene by parathyroid hormone, calcitonin, and 1 alpha, 25(OH)2D3 in intact animals. Endocrinology $1402224-2231$.

Ogunkolade BW, Boucher BJ, Fairclough PD, Hitman GA, Dorudi S, Jenkins PJ \& Bustin SA 2002 Expression of 25-hydroxyvitamin D-1-alpha-hydroxylase mRNA in individuals with colorectal cancer. Lancet 359 1831-1832.

Ohyama Y, Noshiro M \& Okuda K 1991 Cloning and expression of cDNA encoding 25-hydroxyvitamin D3 24-hydroxylase. FEBS Letters 278 195-198.

Ohyama Y, Ozono K, Uchida M, Shinki T, Kato S, Suda T, Yamamoto O, Noshiro M \& Kato Y 1994 Identification of a vitamin $\mathrm{D}$-responsive element in the 5 '-flanking region of the rat 25-hydroxyvitamin D3 24-hydroxylase gene. Fournal of Biological Chemistry 269 10545-10550.

Oliveira JG, Prados RZ, Guedes AC, Ferreira PC \& Kroon EG 1999 The housekeeping gene glyceraldehyde-3-phosphate dehydrogenase is inappropriate as internal control in comparative studies between skin tissue and cultured skin fibroblasts using Northern blot analysis. Archives of Dermatological Research 291 659-661.

O'Loughlin PD \& Morris HA 1998 Oestrogen deficiency impairs intestinal calcium absorption in the rat. Fournal of Physiology 511 313-322.

Omdahl JL, Morris HA \& May BK 2002 Hydroxylase enzymes of the vitamin D pathway: expression, function, and regulation. Annual Review of Nutrition 22 139-166.

Panda DK, Miao D, Tremblay ML, Sirois J, Farookhi R, Hendy GN \& Goltzman D 2001 Targeted ablation of the 25-hydroxyvitamin D 1 alpha-hydroxylase enzyme: evidence for skeletal, reproductive, and immune dysfunction. PNAS 98 7498-7503.

Shinki T, Ueno Y, DeLuca HF \& Suda T 1999 Calcitonin is a major regulator for the expression of renal 25-hydroxyvitamin D3-1 alpha-hydroxylase gene in normocalcemic rats. PNAS 96 8253-8258.

St-Arnaud R, Messerlian S, Moir JM, Omdahl JL \& Glorieux FH 1997 The 25-hydroxyvitamin D 1-alpha-hydroxylase gene maps to the pseudovitamin D-deficiency rickets (PDDR) disease locus. Journal of Bone and Mineral Research 12 1552-1559.

Thellin O, Zorzi W, Lakaye B, De Borman B, Coumans B, Hennen G, Grisar T, Igout A \& Heinen E 1999 Housekeeping genes as internal standards: use and limits. Fournal of Biotechnology $\mathbf{7 5}$ 291-295.

Tso JY, Sun XH, Kao TH, Reece KS \& Wu R 1985 Isolation and characterization of rat and human glyceraldehyde-3-phosphate dehydrogenase cDNAs: genomic complexity and molecular evolution of the gene. Nucleic Acids Research 13 2485-2502.

Zierold C, Mings J \& DeLuca H 2001 Parathyroid hormone regulates 25-hydroxyvitamin $\mathrm{D}_{3}$-24-hydroxylase mRNA by altering its stability. PNAS 98 13572-13576.

Received in final form 13 March 2003

Accepted 18 March 2003 